\title{
Characterization of adenylyl cyclases in cultured human granulosa cells
}

\author{
G. Asbóth, S. A. Price, J. Bellinger, W. Ledger, D. H. Barlow \\ and A. López Bernal* \\ Nuffield Department of Obstetrics and Gynaecology, University of Oxford, \\ John Radcliffe Hospital, Headington, Oxford OX3 9DU, UK
}

Granulosa cells play an essential role in follicular development and formation of corpora lutea. Many functions of granulosa-lutein cells are controlled by activation of $G$ protein-coupled receptors and the formation of cyclic AMP (cAMP) by adenylyl cyclase. There are at least nine mammalian adenylyl cyclase isoenzymes, which show different sensitivities towards other signalling systems. The aim of this study was to identify the types of adenylyl cyclase present in human granulosa cells and to investigate its functional regulation by $G$ proteins, calcium and the protein kinase $C$ and A pathways. Granulosa cells were obtained from women undergoing IVF. The cells were maintained in primary culture and they consistently expressed mRNA coding for adenylyl cyclase I, III, VI, VII and IX. The signals for adenylyl cyclase $\mathrm{V}$ and VIII were more variable among patients and there was no signal for adenylyl cyclase II. The expression of multiple adenylyl cyclase proteins was confirmed by immunochemistry with subtype-specific antibodies. The formation of cAMP in cultured cells was stimulated many times by hCG $\left(\mathrm{EC}_{50}\right.$ value $\left.4.2 \mathrm{iu} \mathrm{ml}^{-1}\right)$ and by prostaglandin $\mathrm{E}_{2}\left(\mathrm{PGE}_{2} ; \mathrm{EC}_{50}=\right.$ $0.75 \mu \mathrm{mol} \mathrm{l}^{-1}$ ) in a concentration-dependent manner, thus confirming the presence of receptors coupled positively to $G_{s}$. The diterpene forskolin, which stimulates all isoforms of adenylyl cyclase except for adenylyl cyclase IX, increased cAMP formation to higher levels than hCG or $\mathrm{PGE}_{2}$. The strong stimulation by forskolin indicates that adenylyl cyclase IX is unlikely to be the major source of cyclase activity in these cells. Basal and forskolin- or $\mathrm{PGE}_{2}$-stimulated adenylyl cyclase activity was amplified 1.5-2.0 times by phorbol-12,13-dibutyrate, indicating that protein kinase C-sensitive enzymes (for example, adenylyl cyclase types IV, V, VI or VII) may be active in the cells. In contrast, hCG-stimulated activity was inhibited $(76 \pm 6 \%)$ by phorbol ester. Stimulation of $G_{i}$ with the $\alpha$-adrenoceptor agonist clonidine inhibited hCGinduced cyclase activity. This finding indicates that adenylyl cyclase II and IV subtypes, which are stimulated by $\beta \gamma$ subunits released from $G_{i}$, are not predominant. Increases in intracellular free calcium concentrations by the ionophore A23187, the calcium-ATPase inhibitor thapsigargin or by fluprostenol, a selective prostanoid FP receptor agonist, which is known to open calcium channels in granulosa cells, or removal of calcium by EGTA, had no significant effects on basal or forskolin-stimulated formation of cAMP. These results indicate that subtypes adenylyI cyclase I, III and VIII, which are activated by calcium, and adenylyl cyclase $\mathrm{V}$ and $\mathrm{VI}$, which are inhibited by calcium, are not dominant isoforms in granulosa-lutein cells. The protein kinase A inhibitor $\mathrm{H} 89$ had no effects on formation of cAMP; this finding rules out the involvement of adenylyl cyclase $\mathrm{V}$ and $\mathrm{VI}$ subtypes, which are subjected to negative feedback by protein kinase A. These results indicate that adenylyl cyclase VII is the dominant functional isoenzyme in human granulosalutein cells.

\section{Introduction}

Granulosa cells play an essential role in follicular development, oocyte maturation and formation of corpora lutea. Many functions of granulosa-lutein cells are controlled by gonadotrophins, prostaglandins and other agonists through the second messenger cAMP. The intracellular concentra-

*Correspondence

Email: andres.lopezbernal@obstetrics-gynaecology.oxford.ac.uk tion of CAMP is controlled primarily at the level of synthesis; CAMP is formed from ATP by agonist-stimulated adenylyl cyclase (ATP pyrophosphate lyase (cyclizing) EC 4.6.1.1.). Recent studies have identified nine isoforms of adenylyl cyclase, which are expressed unevenly in different tissues (Taussig and Gilman 1995; Sunahara et al., 1996; Hurley, 1999). These isoenzymes, designated adenylyl cyclase I-IX, have similar structures, with two integral membrane domains each constituted by six putative transmembrane stretches (Krupinski et al., 1989) and an active site formed by the interplay of two cytosolic 
domains (Yan et al., 1996). The catalytic core of mammalian adenylyl cyclases consists of a pseudosymmetric heterodimer composed of highly conserved portions of the cytosolic domains, namely regions $\mathrm{C} 1 \mathrm{a}$ and $\mathrm{C} 2 \mathrm{a}$ (Hanoune et al., 1997; Yan et al., 1997), which are able to bind one molecule of $\mathrm{G \alpha}_{\mathrm{s}}$, one molecule of forskolin and one molecule of ATP (Tesmer and Sprang, 1998). A soluble form of adenylyl cyclase has been constructed by linkage of $\mathrm{C} 1 \mathrm{a}$ and $\mathrm{C} 2 \mathrm{a}$ regions and this has helped in studies of the regulation of the enzyme (Taussig and Gilman, 1995; Dessauer and Gilman, 1996).

Adenylyl cyclase is stimulated by receptors that promote the dissociation of heterotrimeric $\mathrm{G}_{\mathrm{s}}$ proteins. The released $\mathrm{G} \alpha_{\mathrm{s}}-\mathrm{GTP}$ unit binds and activates the cytosolic catalytic domains of the enzyme (Hurley, 1999). Although every known adenylyl cyclase isoform is stimulated by $\mathrm{G} \alpha_{\mathrm{s}}-\mathrm{GTP}$ (Taussig and Gilman, 1995; Sunahara et al., 1996), the effects of other signalling factors are less uniform due to heterogeneous expression of cytosolic regulatory domains on the enzyme. Adenylyl cyclase isoforms have been classified into four groups according to their mode of regulation (Hanoune et al., 1997). For example, group 1 isoforms (adenylyl cyclase subtypes I, III and VIII) are stimulated by calcium and calmodulin (Krupinski et al., 1989; Choi et al., 1992; Cali et al., 1994), whereas group 3 isoforms (types $\mathrm{V}$ and $\mathrm{VI}$ ) are inhibited by increases in intracellular calcium concentrations (Fagan et al., 1998). Protein kinase $C$ exerts a stimulatory effect on group 2 (adenylyl cyclase II, IV and VII) (Taussig and Gilman, 1995; Sunahara et al., 1996) and group 3 (adenylyl cyclase V and VI) (Sunahara et al., 1996) subtypes. In contrast, cAMP-dependent protein kinase $\mathrm{A}$ has a negative feedback effect on adenylyl cyclase $\mathrm{V}$ and VI (group 3) (Iwami et al., 1995). The heterotrimeric protein $G_{i}$ has dual effects: the $\mathrm{G} \alpha_{i}-\mathrm{GTP}$ complex inhibits adenylyl cyclase $\mathrm{V}$ and $\mathrm{VI}$, whereas the $\beta \gamma$ subunits released from $\mathrm{G}_{\mathrm{i}}$ inhibit adenylyl cyclase I. Moreover, adenylyl cyclase II, adenylyl cyclase IV and probably adenylyl cyclase VII are stimulated by G $\beta \gamma$ subunits (Hurley, 1999). Group 4 isoforms (at present only adenylyl cyclase IX has been characterized) are insensitive to both calcium and $\mathrm{G} \beta \gamma$ subunits (Taussig and Gilman, 1995; Hanoune et al., 1997) but are inhibited by the phosphatase calcineurin (Antoni et al., 1998).

The subtype selective sensitivity towards other second messenger systems facilitates the 'fine tuning' of cAMP concentrations within cells expressing different isoforms of adenylyl cyclases. The 'cross talk' between separate regulatory systems is especially important in granulosa cells, in which functions controlled by the activation of the LH-hCG receptor, that operate through $\mathrm{G}_{\mathrm{s}}$ and stimulate CAMP formation, may be modulated by paracrine factors produced locally (for example, prostaglandins acting through different second messenger systems).

The aim of the present study was to characterize adenylyl cyclase activity in human granulosa cells and to identify functional isoforms of adenylyl cyclase. An in vitro system was used to culture human granulosa cells obtained from stimulated IVF cycles (López Bernal et al., 1995). RT-PCR was used to determine the expression of mRNAs coding for adenylyl cyclase isoforms and the expression of adenylyl cyclase protein was demonstrated by immunochemistry. Furthermore, cAMP accumulation in cells stimulated by hCG, prostaglandin $E_{2}$ and forskolin under different regulatory conditions was measured.

\section{Materials and Methods}

\section{Materials}

$\left[2,8^{-}{ }^{3} \mathrm{H}\right]$-adenosine- $3^{\prime} 5^{\prime}$-cyclic phosphate was obtained from Amersham International PIc (Little Chalfont). Percoll, antibiotic antimycotic solution (penicillin, streptomycin and amphotericin B), hyaluronidase type IV-S, Trypan blue, vitamin E, sodium selenite, adenosine-3' $5^{\prime}$-cyclic phosphate, 1,1,2-trichlorotrifluoroethane, tri-n-octylamine, EDTA, theophylline, indomethacin, prostaglandin $\mathrm{E}_{2}$ and nifedipine were from Sigma Chemical Co. Ltd (Poole). Forskolin, clonidine- $\mathrm{HCl}$, phorbol-12,13-dibutyrate, EGTA, staurosporine, thapsigargin, H89 and A23187 were from Calbiochem-Novachem (Beeston). hCG was from Serono Labs UK Ltd (Hertfordshire). Fluprostenol was supplied by R. Coleman (formerly at Glaxo, Stevenage). Tissue culture reagents were from Life Sciences BRL (Inchinan). All other reagents were commercial preparations of the highest available purity.

Custom oligonucleotide primers that were designed to recognize human adenylyl cyclase sequences recorded in the GenBank database were obtained from Life Technologies Ltd (Paisley). Adenylyl cyclase IX primers were developed by J. Patterson (Antoni et al., 1995, 1998). Omniscript $^{\mathrm{TM}}$ RT Kit and Taq PCR Core Kit were purchased from Qiagen (Crawley). DNA molecular weight markers, $10 \times \mathrm{TBE}$, Oligo $\mathrm{p}(\mathrm{dT})_{15}$ and RNase inhibitor were obtained from Roche Diagnostics Limited (Lewes).

Specific polyclonal antibodies for adenylyl cyclase isoforms I, II, III, IV, V, VII and VIII, and their corresponding cognate peptides, were purchased from Santa Cruz Biotechnology (Santa Cruz, CA). Anti-adenylyl cyclase IX antiserum and cognate peptide were provided by F. Antoni (Antoni et al., 1998). DAKO biotin blocking system, biotinylated swine anti-goat/mouse/rabbit $\mathrm{lg}$, rabbit antimouse IgG and streptavidin AP were purchased from DAKO Ltd (Ely). Naphthol AS-MX phosphate free acid, $N$, $\mathrm{N}$-dimethylformamide, levamisole, Phe-Gly-Gly and fast red TR salt were supplied by Sigma-Aldrich Co Ltd. Aquamount was supplied by $\mathrm{BDH}$ Laboratory Supplies (Poole).

\section{Preparation and culture of human granulosa cells}

Granulosa cells were collected with informed consent from women undergoing routine retrieval of oocytes for IVF. Granulosa cells from women with endometriosis or 
polycystic ovaries were excluded. The main indications for IVF were unexplained infertility, tubal damage and male factor infertility. Follicular growth was stimulated by daily injection of gonadotrophins in patients previously desensitized with a long course of GnRH (Al Azemi et al., 2000). Follicles were aspirated $35 \mathrm{~h}$ after administration of 10000 iu hCG (Profasi; Serono labs UK Ltd, Hertfordshire). After removal of any oocytes, cells were collected from follicular fluid by centrifugation at $340 \mathrm{~g}$, washed with Hank's balanced salt solution (HBSS) and centrifuged at $340 \mathrm{~g}$ at room temperature for $30 \mathrm{~min}$ on $40 \%(\mathrm{v} / \mathrm{v})$ Percoll. Granulosa cell layers were subsequently collected from the interface, washed in HBSS and dissipated using $1 \mathrm{mg}$ hyaluronidase $\mathrm{ml}^{-1}$. Viability of cells after dispersion was $80 \%$ as detected by Trypan blue staining and the yield per patient was $0.4-1.5 \times 10^{6}$ cells. Cells were seeded in 24 well plates at $4.0 \times 10^{4}$ cells $\mathrm{cm}^{-2}$ and cultured in Dulbecco's modified Eagle's medium (DMEM): Ham's F12 mix with glutamax (1:1 by volume) medium containing $10 \%(\mathrm{v} / \mathrm{v})$ fetal calf serum, $10 \%(\mathrm{v} / \mathrm{v})$ horse serum, $1 \mu \mathrm{mol}$ vitamin $\mathrm{E} \mathrm{I}^{-1}, 20 \mathrm{nmol}$ sodium selenite $\mathrm{I}^{-1}, 100 \mathrm{U}$ penicillin $\mathrm{ml}^{-1}, 0.1 \mathrm{mg}$ streptomycin $\mathrm{ml}^{-1}$ and $0.25 \mu \mathrm{g}$ amphotericin $\mathrm{B} \mathrm{ml}^{-1}$. The cultures were kept at $37^{\circ} \mathrm{C}$ in a humidified atmosphere of $95 \%$ air, $5 \% \mathrm{CO}_{2}$. Culture medium was exchanged daily and the cells were used within the first week in culture. Under these conditions the cells retained 3ß-hydroxysteroid dehydrogenase and aromatase activities and remained responsive to hCG by increasing progesterone output (López Bernal et al., 1995).

\section{RNA isolation}

Total cellular RNA was prepared using a modification of the guanidine-isothiocyanate method (Chirgwin et al., 1979). In brief, cells (approximately $10^{6}$ ) were solubilized in $3 \mathrm{ml}$ of $4 \mathrm{~mol}$ guanidium isothiocyanate $\mathrm{I}^{-1}$ containing 5 g sodium $\mathrm{N}$-lauryl sarcosine $\mathrm{I}^{-1}, 0.7 \%(\mathrm{v} / \mathrm{v})$ mercaptoethanol and $25 \mathrm{mmol}$ sodium citrate $\mathrm{I}^{-1}(\mathrm{pH} 7.0)$, and layered onto an $8.5 \mathrm{ml}$ cushion of $5.7 \mathrm{~mol}$ caesium chloride $\mathrm{I}^{-1}$ containing $10 \mathrm{mmol} \mathrm{Na}_{2}$ EDTA I$^{-1}$ and sedimented at $175000 \mathrm{~g}$ for $20 \mathrm{~h}$ at $20^{\circ} \mathrm{C}$ in a Beckman SW 41Ti-rotor. RNA concentrations were determined by UV absorption at $260 \mathrm{~nm}$. The integrity of the 28 and $18 \mathrm{~S}$ ribosomal RNA was assessed by agarose gel electrophoresis.

\section{RT-PCR amplification}

First strand CDNA synthesis using Omniscript ${ }^{\mathrm{TM}} R T$. Total RNAs from human cultured granulosa cells were used as templates for first strand cDNA synthesis using Oligo-p $(\mathrm{dT})_{15}$ primer and Omniscript $\mathrm{T}^{\mathrm{TM}}$ reverse transcriptase supplied in Omniscript ${ }^{\mathrm{TM}} \mathrm{RT}$ kit. First strand cDNA synthesis was carried out in a $40 \mu \mathrm{l}$ reaction volume containing $1 \mu \mathrm{g}$ total RNA, $10 \mu \mathrm{mol}$ Oligo-p $(\mathrm{dT})_{15} \mathrm{I}^{-1}$, $0.5 \mathrm{mmol}$ deoxynucleoside triphosphates $\mathrm{I}^{-1}, 10 \cup \mathrm{RNase}$ inhibitor and $4 \mathrm{U}$ Omniscript ${ }^{\mathrm{TM}}$ reverse transcriptase. Transcription was carried out at $37^{\circ} \mathrm{C}$ for $1 \mathrm{~h}$ before storage at $-70^{\circ} \mathrm{C}$. Human brain total RNA was also prepared as described above and used as a control tissue in RT-PCR.

Amplification of first strand $c D N A$ s by PCR. Messenger RNAs encoding adenylyl cyclase isoforms I, II, VII, VIII, IX and for $\mathrm{G} \alpha_{\mathrm{S}}$ were amplified as described by Price et al. (2000) using oligodeoxynucleotide primers based on human sequences published in the GenBank database. A HotStart PCR protocol was used to amplify adenylyl cyclase III. Additional primers were designed to amplify adenylyl cyclases $\mathrm{V}$ and $\mathrm{VI}$ using a partial sequence for Homo sapiens cardiac adenylyl cyclase types $\mathrm{V}$ and $\mathrm{VI}$ (Raimundo et al., 1999). For adenylyl cyclase $V$ : forward primer of 20 bases representing nucleotides $41-60$ and a reverse primer of 20 bases complementary to nucleotides 231-212. For adenylyl cyclase VI: forward primer of 18 bases representing nucleotides $7-24$ and a reverse primer of 20 bases complementary to nucleotides 197-178. Forty cycles of PCR were required to amplify mRNA for adenylyl cyclases $\mathrm{V}$ and VI. None of the primers used amplified a product from genomic DNA (data not shown).

Electrophoresis of PCR products. The PCR products from the amplification reaction were resolved using a $2 \%$ $(\mathrm{w} / \mathrm{v})$ agarose gel and the DNA bands were visualized by ethidium bromide staining and UV illumination. All primer pairs produced a single PCR product band of the expected size; however, primers designed to amplify cDNA coding for $\mathrm{G} \alpha_{\mathrm{s}}$ produced a double banded product corresponding to $\mathrm{G} \alpha_{\mathrm{s}}$ large and $\mathrm{G} \alpha_{\mathrm{s}}$ small.

Sequencing of PCR products. The identities of the PCR products obtained were confirmed by Dye Terminator Sequencing (DNA Sequencing Facility, Department of Biochemistry, University of Oxford, Oxford) using the primers designed for each isoform of adenylyl cyclase.

\section{Immunocytochemistry}

Granulosa cells were cultured on glass coverslips for $48 \mathrm{~h}$, fixed with acetone for $10 \mathrm{~min}$, rinsed in distilled water and Tris-buffered saline (TBS) for $5 \mathrm{~min}$, and then incubated in avidin solution followed by biotin solution for 10 min to block endogenous biotin and to inhibit non-specific background staining. The cells were incubated for 30 min with primary antibody diluted optimally to $2 \mu \mathrm{g}$ $\mathrm{ml}^{-1}$ in TBS, washed and incubated for a further $30 \mathrm{~min}$ with biotinylated secondary antibody diluted 1:100 in TBS. The cells were incubated for 30 min with streptavidin (1:200 in TBS) followed by 30 min incubation with Fast Red Substrate (1 mg Naphthol AS-MX phosphate free acid dissolved in $0.1 \mathrm{ml} \mathrm{N}, \mathrm{N}$-dimethylformamide and added to $4.9 \mathrm{ml}$ of $0.1 \mathrm{~mol}^{-1} \mathrm{ris}^{-1}(\mathrm{pH} 8.2)$ containing $5 \mu \mathrm{l}$ of $1 \mathrm{~mol}$ levamisole $\mathrm{I}^{-1}, 50 \mu \mathrm{l}$ of $100 \mathrm{mmol}$ Phe-Gly-Gly $\mathrm{I}^{-1}$ and $5 \mathrm{mg}$ Fast Red TR salt). Control reactions included IgG instead of the antibodies or antibodies preabsorbed with their cognate peptides. Coverslips were counterstained 
with haematoxylin and mounted onto glass slides using Aquamount.

\section{Measurement of intracellular cAMP}

The cells were washed with HBSS for $10 \mathrm{~min}$ at $37^{\circ} \mathrm{C}$ and preincubated with the phosphodiesterase inhibitor theophylline $\left(5 \mathrm{mmol}^{-1}\right)$ and the prostaglandin synthesis inhibitor indomethacin $\left(10 \mu \mathrm{mol} \mathrm{I} \mathrm{I}^{-1}\right)$ in HBSS for $10 \mathrm{~min}$. In several experiments the preincubation mixture also contained other specific enzyme inhibitors, as described in the results section. All compounds were dissolved initially in ethanol or dimethylsulphoxide (DMSO), and solvent controls were included in the experiments. Agonists were added in $0.5 \mathrm{ml} \mathrm{HBSS}$ and the cells were incubated at $37^{\circ} \mathrm{C}$ for $10 \mathrm{~min}$ in the presence of theophylline and indomethacin. The reaction was stopped by replacing the incubation fluid with $0.5 \mathrm{ml}$ ice-cold $5 \%(\mathrm{v} / \mathrm{v})$ perchloric acid. The cells were scraped, centrifuged for $10 \mathrm{~min}$ at $1000 \mathrm{~g}$ and the acid soluble fraction was neutralized by the addition of 1.3 volumes of 1,1,2-trichlorotrifluoroethane: tri-n-octylamine $(1: 1, v / v)$. The mixture was shaken intensively for $2 \mathrm{~min}$, centrifuged at $1000 \mathrm{~g}$ for 10 min and the upper phase was stored at $-20^{\circ} \mathrm{C}$ until used for cAMP estimations. cAMP was measured by the competitive protein-binding assay of Brown et al. (1971) as described by López Bernal et al. (1991) using [ $\left.{ }^{3} \mathrm{H}\right] \mathrm{cAMP}$ as tracer. Radioactivity was measured in $5 \mathrm{ml}$ Wallac OptiPhase 'HiSafe' scintillation cocktail (Fisons, Loughborough) using a Beckman LS 5000 liquid scintillation counter. Values were expressed in d.p.m., taking into account counting efficiency (typically $40-51 \%$ for ${ }^{3} \mathrm{H}$ ). All cAMP estimations were performed in quadruplicate. Data were plotted and analysed using Prism 2.01 (Graphpad Software Inc, San Diego, CA).

\section{Protein measurement}

Protein was determined by the bicinchoninic acid method using a commercially available kit (Pierce, Rockford, IL).

\section{Results}

\section{Expression of adenylyl cyclase isoforms in granulosa cells}

The results of the mRNA analysis are shown (Fig. 1). Cells from four different donors were studied and there was consistent expression of mRNA coding for adenylyl cyclase I, III, VI, VII and IX. The signals for adenylyl cyclase $\mathrm{V}$ and VIII were more variable among patients and there was no apparent signal for adenylyl cyclase II, although the message for this isoform was detected clearly in brain tissue. The quality of the PCR technique was confirmed by the detection of message for $G \alpha_{\mathrm{s}}$ large and $\mathrm{G} \alpha_{\mathrm{S}}$ small as expected (Europe-Finner et al., 1997; Price et al., 2000).
Staining of granulosa cells with specific adenylyl cyclase antibodies confirmed the mRNA data and revealed the presence of several adenylyl cyclase proteins in the cells, including group 1 (adenylyl cyclase I, III and VIII), group 2 (adenylyl cyclase IV and VII), group 3 (adenylyl cyclase V) and group 4 (adenylyl cyclase IX) isoforms (Fig. 2). There was no staining for adenylyl cyclase II, thereby confirming the PCR data. In all cases the staining was virtually abolished by pre-incubating the antibodies with their cognate peptide, confirming the specificity of the reaction.

\section{Receptor-stimulated adenylyl cyclase activity}

The accumulation of cAMP in cultured human granulosa cells was stimulated, in a concentration dependent manner, by hCG and $\mathrm{PGE}_{2}$ up to 50 times compared with basal CAMP content (Fig. 3). The $\mathrm{EC}_{50}$ values were $4.2 \pm 0.1 \mathrm{iu} \mathrm{hCG} \mathrm{ml}{ }^{-1}(n=3)$ and $0.75 \pm 0.18 \mu \mathrm{mol} \mathrm{PGE}_{2}$ $\mathrm{I}^{-1}(n=7)$. The diterpene forskolin increased cAMP formation, but although this effect was concentration dependent, obvious signs of saturation were not observed at the highest concentration used $\left(100 \mu \mathrm{mol} \mathrm{I}^{-1}\right)$. These results confirm that there is adenylyl cyclase activity in cultured granulosa cells and that it is functionally activated by two independent receptors coupled to $\mathrm{G} \alpha_{\mathrm{s}}$.

\section{Effect of protein kinases}

Basal, forskolin- and $\mathrm{PGE}_{2}$-stimulated formation of CAMP was amplified by the protein kinase $C$ activator phorbol-12,13-dibutyrate (Fig. 4). In contrast, hCG-stimulated formation of CAMP was inhibited strongly by phorbol-12,13-dibutyrate. This inhibition was reversed by the protein kinase $C$ inhibitor staurosporine $\left(1 \mu \mathrm{mol} \mathrm{I}^{-1}\right)$. The selective cAMP dependent protein kinase (protein kinase A) inhibitor $\mathrm{H} 89$ had no effect on forskolin-, hCG- or $\mathrm{PGE}_{2}$-stimulated formation of CAMP (Fig. 5).

\section{Effect of $G_{i}$ activation}

When granulosa cells were incubated with clonidine, which signals through $\alpha$-adrenoceptors coupled to $G_{i}$ (Stevens and Pyne, 1995; López Bernal et al., 1995), hCGstimulated CAMP formation was inhibited significantly (Fig. 6). The $I C_{50}$ value of clonidine was $1.9 \pm 1.1 \mathrm{nmol}$ $\mathrm{I}^{-1}(n=3)$.

\section{Role of calcium}

Increasing $\mathrm{Ca}^{2+}$ concentrations using the ionophore A23187 $\left(10 \mu \mathrm{mol} \mathrm{I}^{-1}\right)$, the calcium-ATPase inhibitor thapsigargin $\left(100 \mathrm{nmol} \mathrm{I}^{-1}\right)$ or the stable prostaglandin analogue fluprostenol $\left(0.1-1.0 \mu \mathrm{mol} \mathrm{I}^{-1}\right)$, which is known to open calcium channels in granulosa cells (Carrasco et al., 1997), had no significant effect on basal or forskolinstimulated formation of cAMP. Chelating extracellular cal-

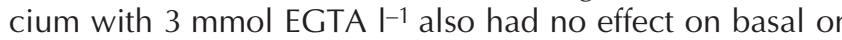
forskolin-stimulated formation of cAMP (Fig. 7 and data not shown). 


\section{Discussion}

This is the first comprehensive molecular and functional characterization of adenylyl cyclase in human granulosalutein cells. The results of mRNA analysis and protein immunochemistry indicate that there are multiple isoforms of adenylyl cyclase in granulosa cells. Adenylyl cyclases are ubiquitous enzymes but they exhibit a degree of tissue and receptor selectivity that allows cell- and agonist-specific responses. Inclusion of the broad-spectrum phosphodiesterase inhibitor theophylline in the incubation system used in the present study ensured that any potential effects on the catabolism of cAMP were neutralized. Therefore, the observed changes in CAMP accumulation represented changes in adenylyl cyclase activity. The formation of CAMP in granulosa cells was clearly stimulated by hCG and $\mathrm{PGE}_{2}$, which act through $\mathrm{G}$ protein-coupled receptors. Receptor activation promotes the dissociation of GDP from $\mathrm{G} \alpha_{\mathrm{s}}$ subunits and its replacement by the more abundant GTP, followed by the release of $\mathrm{G \alpha}_{\mathrm{s}}$-GTP from the $\mathrm{G} \beta \gamma$ subunit dimer. Active (GTP bound) $\mathrm{G} \alpha_{\mathrm{s}}$ binds to adenylyl cyclase, thus promoting the association of $\mathrm{C} 1 \mathrm{a}$ and $\mathrm{C} 2 \mathrm{a}$ and the formation of the active centre on adjoining faces of these cytosolic domains (Yan et al., 1997).

Forskolin also promotes the formation of the catalytic core of most mammalian adenylyl cyclases by binding to $\mathrm{C} 1 \mathrm{a}$ and $\mathrm{C} 2 \mathrm{a}$ at sites different from those involving $\mathrm{G} \alpha_{\mathrm{s}}$ (Yan et al., 1998). However, forskolin did not appear to stimulate mouse adenylyl cyclase IX, when it was expressed heterologously in Sf9 cells (Premont et al., 1996) or when the cytosolic domains of adenylyl cyclase IX were expressed in Escherichia coli (Yan et al., 1997). The soluble form of adenylyl cyclase IX is functional, can be stimulated by $\mathrm{G \alpha}_{\mathrm{s}}$ and was rendered forskolin-sensitive by mutating Tyr1082 to Leu (Yan et al., 1998). Very moderate stimulation by forskolin was observed when adenylyl cyclase IX was expressed in HEK293 cells (Premont et al., 1996) or studied in the AtT20 tumour cell line (Antoni et al., 1995). In the present study, forskolin proved to be a very effective stimulator of adenylyl cyclase activity compared with hCG and $\mathrm{PGE}_{2}$, indicating that adenylyl cyclase IX is not the single most active isoform in human granulosa cells.

Protein kinase $\mathrm{C}$ has a complex role in the regulation of granulosa-lutein cells, which may be mediated, in part, by effects on CAMP production. Protein kinase $C$ activation stimulates progesterone production in bovine (Brunswig et al., 1986) and human granulosa-lutein cells (Jalkanen et al., 1987). In contrast, protein kinase $C$ inhibits acute (Abayasekara et al., 1993) and long-term (Ristimäki et al., 1997) effects of hCG in cultured human granulosa-lutein cells. In the present study, activation of protein kinase C using phorbol dibutyrate enhanced basal, forskolin- and $\mathrm{PGE}_{2}$-stimulated accumulation of cAMP. As forskolin activates adenylyl cyclase without the intervention of $G$ proteins, these results indicate that protein kinase $\mathrm{C}$ has a direct effect on enzyme activity. These results support
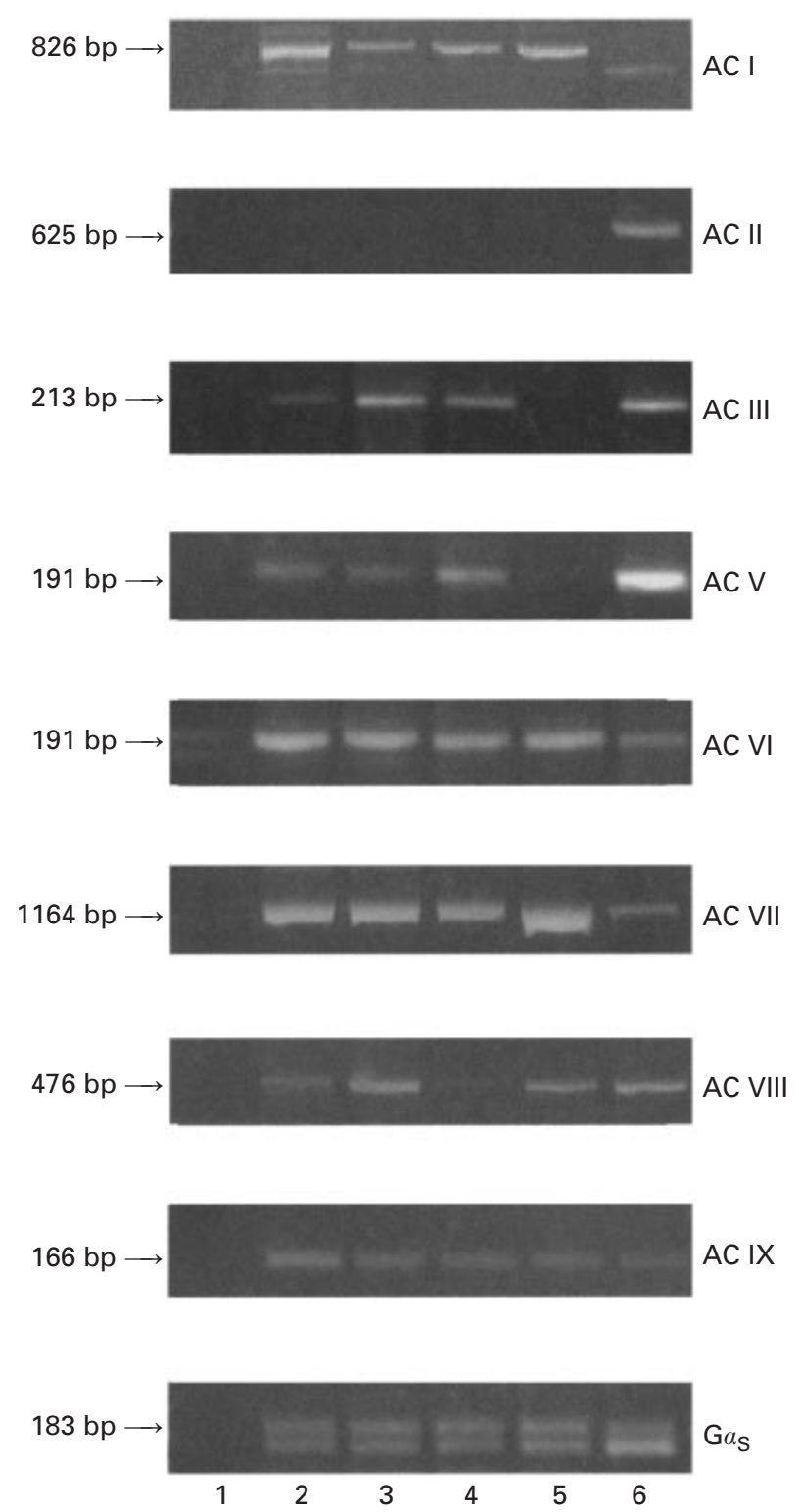

Fig. 1. Identification of human granulosa adenylyl cyclase (AC) and $G \alpha_{s}$ cDNAs. RT-PCR was performed and the cDNAs were resolved on a $2 \%(\mathrm{w} / \mathrm{v})$ agarose gel and visualized by ethidium bromide staining and subsequent UV illumination. Lane 1: negative control, reverse transcription performed using water rather than RNA, with subsequent PCR. Lanes 2, 3, 4 and 5: granulosa cell cDNA from four different donors. Lane 6: human brain cDNA as positive control.

those of Jalkanen et al. (1987) and Wheeler and Veldhuis (1989), who found that phorbol esters facilitated forskolinstimulated generation of cAMP in freshly isolated human and pig luteal cells, respectively. In contrast, other groups have found that phorbol ester treatment has no effect on accumulation of CAMP in primary cultures of rat (Shinohara et al., 1985; Davis et al., 1989a) or bovine luteal cells (Davis 1992) stimulated with cholera toxin or 

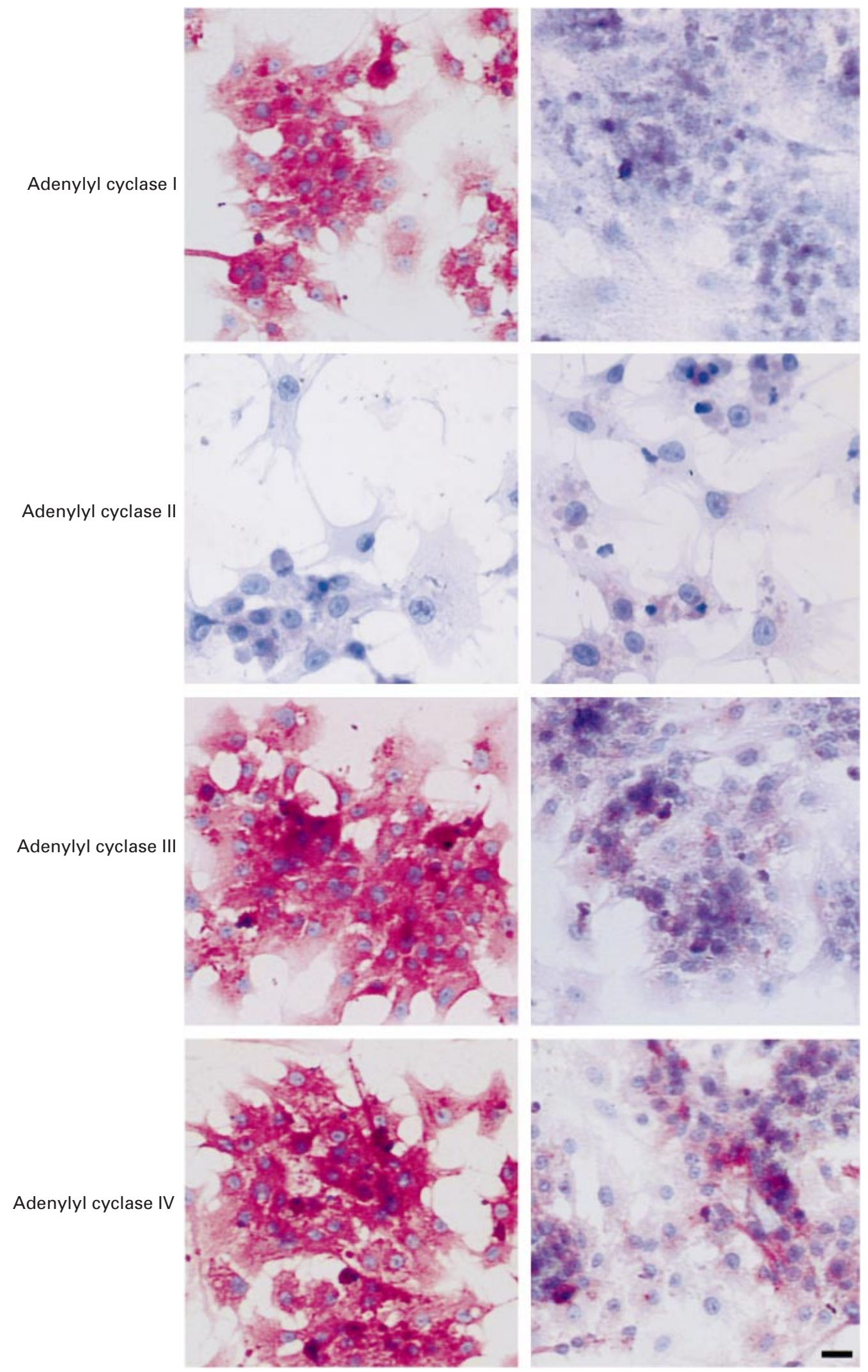

Fig. 2. For legend see facing page. 


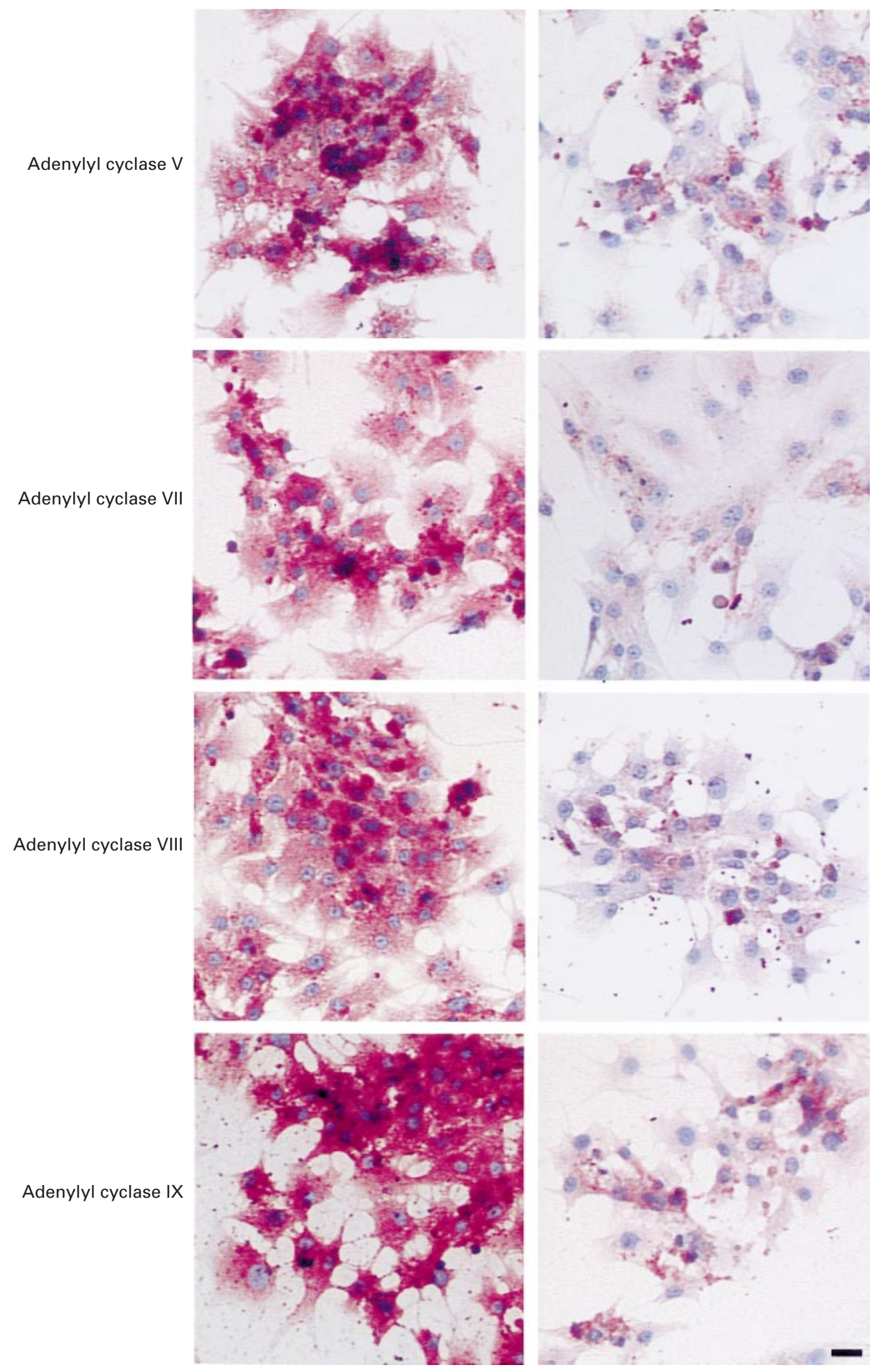

Fig. 2. Immunochemical demonstration of adenylyl cyclases in cultured human granulosa cells using isotype-specific antibodies (left-hand column). Cell staining was performed by the avidin-biotin method using Fast Red substrate. Corresponding control reactions using antibodies preabsorbed with their cognate peptides are shown in the right-hand column. Scale bars represent $50 \mu \mathrm{m}$. 


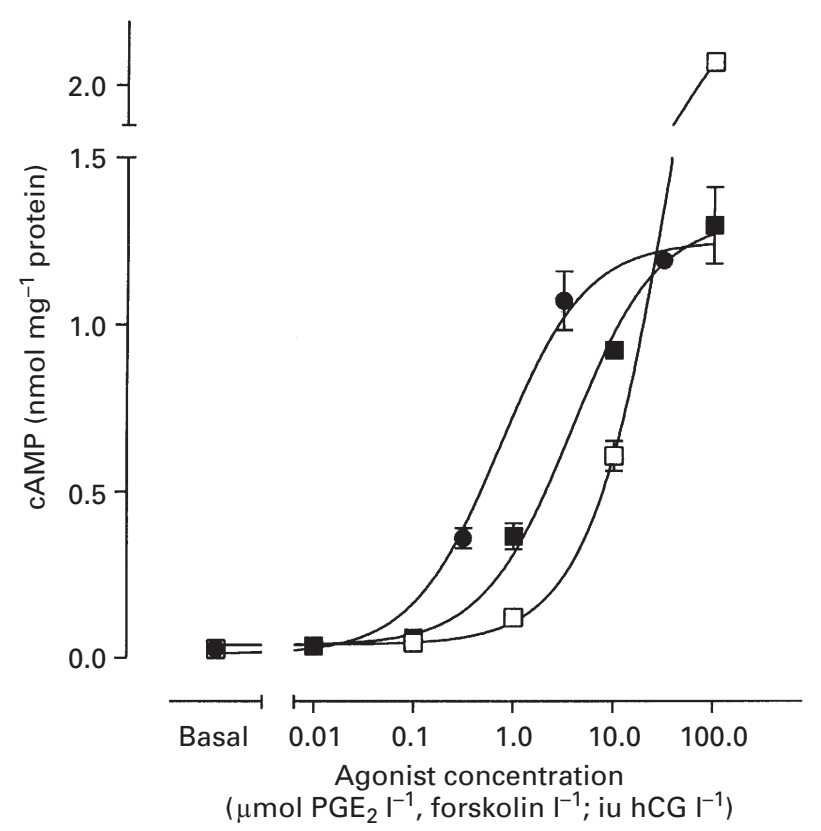

Fig. 3. Effects of hCG (ם), $\mathrm{PGE}_{2}(\mathbf{)})$ and forskolin ( $\square$ ) on formation of cAMP in cultured human granulosa cells. Cells were incubated in medium containing $5 \mathrm{mmol}$ theophylline $\mathrm{I}^{-1}$ and $10 \mu \mathrm{mol}$ indomethacin $\mathrm{I}^{-1}$ and were stimulated with hCG, $\mathrm{PGE}_{2}$ or forskolin for $10 \mathrm{~min}$ at $37^{\circ} \mathrm{C}$. The reaction was stopped by adding cold perchloric acid and cAMP was measured from the acid soluble supernatant. Each data point represent the mean \pm SEM of four parallel incubations, using cells pooled from three patients. Similar results were found in another experiment, using cells pooled from four patients (data not shown).

forskolin. Protein kinase C exerts isotype-specific effects on isoforms of adenylyl cyclase. Phorbol ester treatment increased basal and $\mathrm{G} \alpha_{\mathrm{s}}$-stimulated activity of the heterologously expressed adenylyl cyclase II, with a parallel increase in phosphorylation of the enzyme protein (Jacobowitz and lyengar 1994). Similarly, basal and forskolin-stimulated formation of cAMP was enhanced with adenylyl cyclase II, VII and V (Jacobowitz et al., 1993; Watson et al., 1994; Kawabe et al., 1994). Receptor and $\mathrm{G} \alpha_{\mathrm{s}}$-stimulated, but not basal or forskolin-stimulated, formation of CAMP was increased by phorbol ester treatment in HT4 cells expressing adenylyl cyclase I and VI (Morimoto and Koshland, Jr, 1994). The results of the present study, which indicate that protein kinase $C$ activation has a stimulatory effect, also indicate that isoforms of adenylyl cyclase, such as adenylyl cyclase II, IV, V, VI or VII, are probably present in granulosa cells. However, another layer of complexity may arise from the fact that cells express different isoforms of protein kinase C, which may have different effects on the activation of adenylyl cyclase (Kawabe et al., 1994). This fact may explain the apparently contradictory results. For example, adenylyl cyclase $V$ and VI, expressed in HEK 293 cells, remained unaffected by

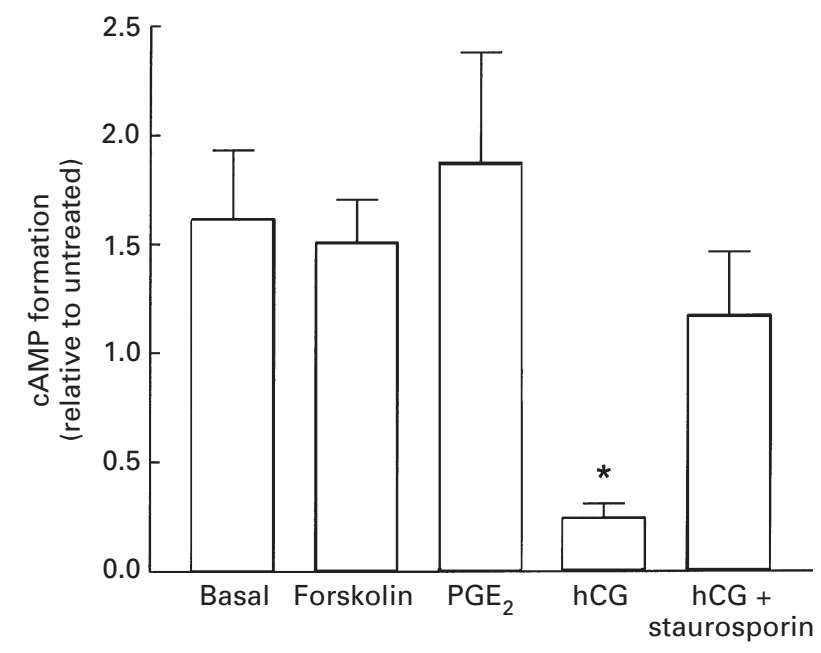

Fig. 4. Effects of protein kinase $C$ activation on formation of cAMP in cultured human granulosa cells. Cells were incubated in buffer containing $5 \mathrm{mmol}$ theophylline $\mathrm{I}^{-1}$ and $10 \mu \mathrm{mol}$ indomethacin $\mathrm{I}^{-1}$, and were stimulated with $1 \mu \mathrm{mol}$ forskolin $\mathrm{I}^{-1}$, $10 \mathrm{iu}$ hCG $\mathrm{ml}^{-1}$ or $1 \mu \mathrm{mol} \mathrm{PGE}_{2} \mathrm{I}^{-1}$ for $10 \mathrm{~min}$ at $37^{\circ} \mathrm{C}$ with and without $1 \mu \mathrm{mol}$ phorbol-12,13-dibutyrate $\mathrm{I}^{-1}$ or phorbol-12,13dibutyrate plus $1 \mu \mathrm{mol}$ staurosporin $\mathrm{I}^{-1}$. The reaction was stopped by the addition of cold perchloric acid and cAMP was measured from the acid soluble supernatant. Data are shown as relative stimulation by phorbol-12,13-dibutyrate versus untreated cells. Values are mean \pm SEM of three experiments, using cells obtained from different patients. Note that phorbol-12,13-dibutyrate enhanced basal, forskolin- and $\mathrm{PGE}_{2}$-activated adenylyl cyclase activity, but depressed hCG-stimulated activity very significantly $\left({ }^{*} P<0.01\right)$. The effect of phorbol-12,13-dibutyrate was blocked completely by staurosporin.

phorbol ester treatment (Jacobowitz et al., 1993) but were highly stimulated when treated with protein kinase $C$ in a purified form (Kawabe et al., 1994). Nevertheless, the moderate activation observed in the present study does not support the involvement of adenylyl cyclase $V$ in human granulosa cells, as adenylyl cyclase $\mathrm{V}$ is activated directly five to 20 times by at least two isozymes of protein kinase C (Kawabe et al., 1994).

Human granulosa cells express functional $\mathrm{PGF}_{2 \alpha}$ receptors positively coupled to phospholipase C (Carrasco et al., 1997). However, in our experiments, fluprostenol had no effect on accumulation of CAMP, although stimulation of protein kinase $\mathrm{C}$ by diacylglycerol liberated as a consequence of activation of phospholipase $C$ would be expected. Perhaps the level of protein kinase $C$ stimulation achieved with phorbol esters exceeds the stimulation from transient increases in diacylglycerol induced by fluprostenol. Similarly, in bovine luteal cells, phorbol ester treatment inhibited $\mathrm{LH}$-induced activation of phospholipase C, but $\mathrm{PGF}_{2 \alpha}$ had no effect (Davis, 1992). $\mathrm{PGF}_{2 \alpha}$ and cloprostenol inhibited hCG-stimulated accumulation of cAMP in cultured human granulosa-lutein cells (Davis et al., 1989b; Michael and Webley, 1991; Abayasekara et 


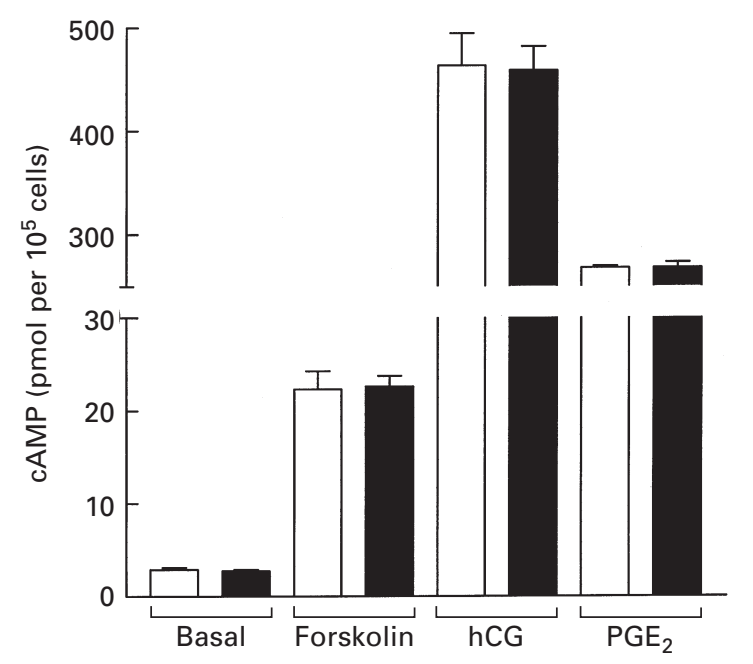

Fig. 5. Effects of the protein kinase A inhibitor $\mathrm{H} 89$ on formation of CAMP in granulosa cells. Cells were incubated in buffer containing $5 \mathrm{mmol}$ theophylline $\mathrm{I}^{-1}$ and $10 \mu \mathrm{mol}$ indomethacin $\mathrm{I}^{-1}$ with (ם) and without $(\square) 10 \mu \mathrm{mol} \mathrm{H89} \mathrm{I}^{-1}$. Cells were stimulated with $1 \mu \mathrm{mol}$ forskolin $\mathrm{I}^{-1}, 10$ iu hCG m I-1 or $1 \mu \mathrm{mol} \mathrm{PGE}_{2} \mathrm{I}^{-1}$ for $10 \mathrm{~min}$ at $37^{\circ} \mathrm{C}$. The reaction was stopped by the addition of $500 \mu \mathrm{l}$ ice cold perchloric acid and cAMP was measured from the acid soluble supernatant. Values are mean \pm SEM of four estimations in a representative experiment. Similar results were obtained in two other experiments using cells from different patients (data not shown).

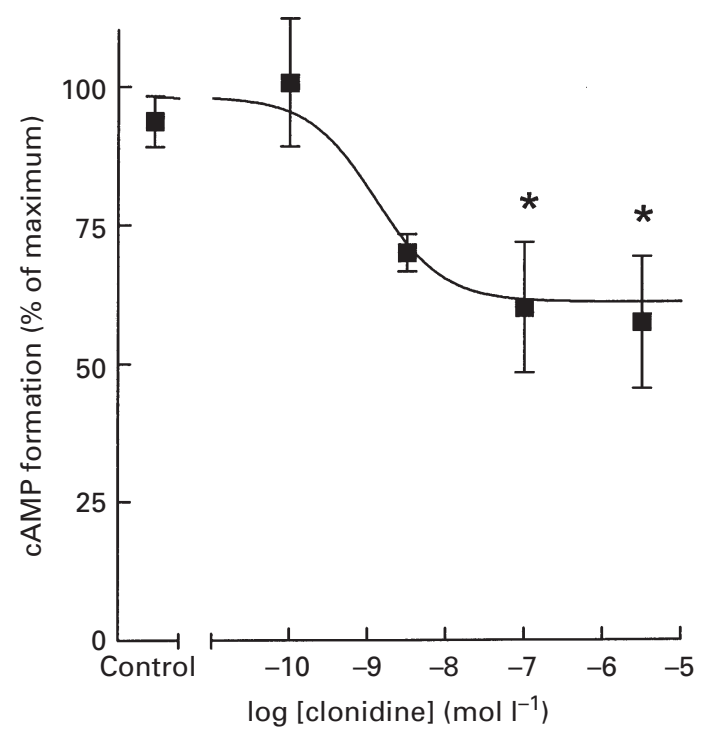

Fig. 6. Effects of clonidine on hCG-stimulated formation of cAMP in cultured human granulosa cells. Cells were incubated in buffer containing $5 \mathrm{mmol}$ theophylline $\mathrm{I}^{-1}, 10 \mu \mathrm{mol}$ indomethacin $\mathrm{I}^{-1}$ and 10 iu hCG ml-1 for $10 \mathrm{~min}$ at $37^{\circ} \mathrm{C}$ with different concentrations of clonidine. Control incubations contained no clonidine. The reaction was stopped with perchloric acid, and CAMP was measured in the acid soluble supernatant. Data are shown as percentages of maximal stimulation. Values are mean \pm SEM of three different experiments. ${ }^{*} V$ alue is significantly different from control $(P<0.05)$.

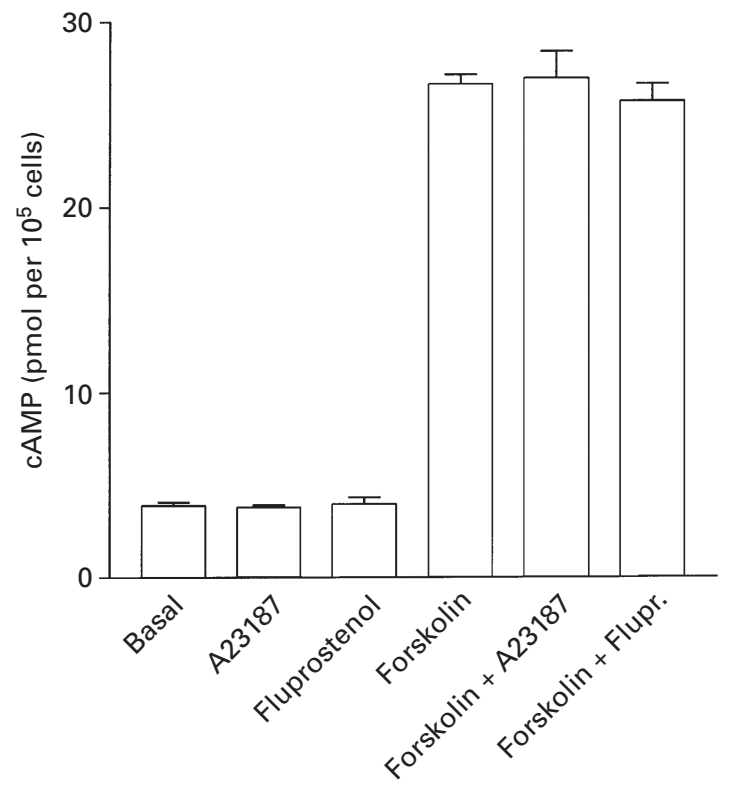

Fig. 7. Effects of changes in calcium concentration on formation of cAMP in granulosa cells. Cells were incubated in buffer containing $5 \mathrm{mmol}$ theophylline $\mathrm{I}^{-1}$ and $10 \mu \mathrm{mol}$ indomethacin $\mathrm{I}^{-1}$ and were stimulated with $1 \mu \mathrm{mol}$ forskolin $\mathrm{I}^{-1}$ for $10 \mathrm{~min}$ at $37^{\circ} \mathrm{C}$. Calcium concentration was influenced by the addition of $5 \mu \mathrm{mol}$ A23187 $\mathrm{I}^{-1}$ or $0.1 \mu \mathrm{mol}$ fluprostenol $\mathrm{I}^{-1}$. The reaction was stopped by the addition of cold perchloric acid and cAMP was measured in the acid soluble supernatant. Values are mean \pm SEM of four incubations in a representative experiment. Similar results were obtained in two other experiments using cells from different patients (data not shown).

al., 1993) and in marmoset monkey luteal tissue (Michael and Webley, 1993), but remained ineffective in cells preincubated overnight with hCG or other agents that increase cAMP content (Michael and Webley, 1991).

Adenylyl cyclase activity can also be subjected to negative feedback by cAMP-sensitive protein kinase (protein kinase $\mathrm{A}$ ). Both type $\mathrm{V}$ and $\mathrm{VI}$ sequences have a conserved putative protein kinase $\mathrm{A}$ phosphorylation site at the $\mathrm{C} 1 \mathrm{a}$ domain near the transmembrane span 7 . This site is not expressed in other adenylyl cyclases (Premont et al., 1992). Protein kinase A phosphorylates and inactivates adenylyl cyclase types $\mathrm{V}$ and $\mathrm{VI}$ directly (Iwami et al., 1995). In the present study, the selective protein kinase $A$ inhibitor H89 (Chijiwa et al., 1990) had no effect on basal or hCG- and forskolin-stimulated adenylyl cyclase activity. This observation is in accordance with a low functional activity of adenylyl cyclase $\mathrm{V}$ and $\mathrm{VI}$ in human granulosa cells.

Alpha-adrenoceptors coupled to $G_{i}$ potentially have several effects on adenylyl cyclase activity. Receptor activation leads to the release of $G \alpha_{i}$ and $G \beta \gamma$ subunits. $G \alpha_{i}$ has inhibitory effects on adenylyl cyclase I, V and VI, whereas G $\beta \gamma$ subunits inhibit adenylyl cyclase I but stimulate adenyIyl cyclase II and IV. Under the conditions used in the pre- 
sent study, activation of $\alpha$-adrenoceptors by clonidine had a negative effect on hCG-stimulated accumulation of CAMP. The lack of any apparent stimulatory or additive effects of clonidine is indicative of a low activity of G $\beta \gamma$-responsive adenylyl cyclase II and IV in granulosa cells.

Increasing calcium concentrations using the ionophore A23187, the calcium-ATP-ase inhibitor thapsigargin and fluprostenol, which open calcium channels in granulosa cells (Carrasco et al., 1997), or chelation of calcium by EGTA, had no significant effects on basal and forskolinstimulated formation of cAMP. These results indicate that subtypes adenylyl cyclase I and VIII, which are activated (Krupinski et al., 1989; Choi et al., 1992; Cali et al., 1994), or adenylyl cyclase $\mathrm{V}$ and $\mathrm{VI}$, which are inhibited directly by increases in calcium concentration (Fagan et al., 1998), are not dominant in human granulosa cells. Calcium also exerts indirect inhibitory effects on adenylyl cyclase III via calcium-calmodulin dependent protein kinase II (Wei et al., 1996), whereas adenylyl cyclase IX is inhibited by calcineurin (a calcium-sensitive protein phosphatase 2B) (Antoni et al., 1995). Ford et al. (1996) demonstrated that calcineurin is present in rat luteal cells. The lack of effect of calcium manipulation in the present study is evidence against a functional involvement of adenylyl cyclase III and IX in human granulosa-lutein cells. This contention is in contrast to the bovine corpora lutea, in which calcium has a clear enhancing effect on forskolin-stimulated production of cAMP, implicating that adenylyl cyclase III is involved (Mamluk et al., 1999).

Under the experimental conditions used in the present study, hCG-stimulated adenylyl cyclase activity was attenuated strongly by phorbol ester treatment, confirming previous observations by Davis et al. (1989b) and Abayasekara et al. (1993). Moreover, phorbol ester treatment suppressed FSH-induced adenylyl cyclase activity in rat granulosa cells (Shinohara et al., 1985). In contrast, $\mathrm{PGE}_{2}$-stimulated adenylyl cyclase activity was enhanced by phorbol esters in the present study. This observation highlights possible differences in the coupling of gonadotrophin and prostaglandin receptors to distinct $\mathrm{G}_{\mathrm{s}}$-adenylyl cyclase combinations. There are several $\mathrm{G} \alpha_{\mathrm{s}}$ variants in granulosa cells with potential phosphorylation sites (Europe-Finner et al., 1997), which may be targets for regulation by protein kinase $\mathrm{C}$. Moreover, the receptors themselves may be targets for phosphorylation. Further research should be aimed at identifying receptor-specific combinations of $\mathrm{G}$ protein and isoforms of adenylyl cyclase. Such studies will increase our understanding of the responses of ovarian cells to gonadotrophins, prostaglandins and other regulatory factors that operate through the CAMP pathway, and the cross-talk involvement of other signalling pathways.

The results of the present study demonstrate that there is adenylyl cyclase activity in cultured human granulosa cells that is stimulated strongly by physiological agonists, such as hCG and $\mathrm{PGE}_{2}$, and by forskolin. Adenylyl cyclase activity is insensitive to changes in calcium concentra- tions, G $\beta \gamma$ subunits or protein kinase A inhibitors, but is enhanced by co-activation of protein kinase C. Collectively, these data indicate that the main source of adenylyl cyclase activity in human granulosa-lutein cells is probably adenylyl cyclase VII, an adenylyl cyclase subtype that is expressed widely in mammalian tissues (Watson et al., 1994). Moreover, the presence of mRNA and protein for several isoforms of adenylyl cyclase in human granulosa cells confirms findings in other human and rat tissues (Mhaouty-Kodja et al., 1997; Emala et al., 1998; Leech et al., 1999; Price et al., 2000). This apparent molecular redundancy provides detailed regulatory options and is a mechanism for integrating the responses to various endocrine and paracrine inputs when the functional expression of gonadotrophin, prostanoid and other receptors changes in ovarian cells. These studies should be extended to granulosa and theca cells at different stages of follicular development, and to late luteal cells, to further our understanding of the essential role of the CAMP signalling pathway in ovarian function.

This work was supported by Wellbeing (grant reference L1/96). The authors are grateful to the staff at the Oxford Fertility Unit for their help in the collection of granulosa cells. The authors would like to thank F. Antoni for providing anti-adenylyl cyclase IX antibody and J. M. Paterson for the adenylyl cyclase IX PCR primers.

\section{References}

Abayasekara DR, Michael AE, Webley GE and Flint AP (1993) Mode of action of prostaglandin $\mathrm{F} 2 \alpha$ in human luteinized granulosa cells: role of protein kinase C Molecular and Cellular Endocrinology 97 81-91

Al Azemi M, López Bernal A, Steele J, Gramsbergen I, Barlow D and Kennedy S (2000) Ovarian response to repeated controlled stimulation in in-vitro fertilization cycles in patients with ovarian endometriosis Human Reproduction 15 72-75

Antoni FA, Barnard RJ, Shipston MJ, Smith SM, Simpson J and Paterson JM (1995) Calcineurin feedback inhibition of agonist-evoked cAMP formation Journal of Biological Chemistry 27028 055-28 061

Antoni FA, Palkovits M, Simpson J, Smith SM, Leitch AL, Rosie R, Fink G and Paterson JM (1998) $\mathrm{Ca}^{2+} /$ calcineurin-inhibited adenylyl cyclase, highly abundant in forebrain regions, is important for learning and memory Journal of Neuroscience 18 9650-9661

Brown BL, Albano JD, Ekins RP and Sgherzi AM (1971) A simple and sensitive saturation assay method for the measurement of adenosine $3^{\prime}: 5^{\prime}$ cyclic monophosphate Biochemical Journal 121 561-562

Brunswig B, Mukhopadhyay AK, Budnik LT, Bohnet HG and Leidenberger FA (1986) Phorbol ester stimulates progesterone production by isolated bovine luteal cells Endocrinology 118 743-749

Cali JJ, Zwaagstra JC, Mons N, Cooper DM and Krupinski J (1994) Type VIII adenylyl cyclase. A Ca ${ }^{2+} /$ calmodulin-stimulated enzyme expressed in discrete regions of rat brain Journal of Biological Chemistry 269 12190-12195

Carrasco MP, Asbóth G, Phaneuf S and López Bernal A (1997) Activation of the prostaglandin FP receptor in human granulosa cells Journal of Reproduction and Fertility 111 309-317

Chijiwa T, Mishima A, Hagiwara M, Sano M, Hayashi K, Inoue T, Naito K, Toshioka T and Hidaka H (1990) Inhibition of forskolin-induced neurite outgrowth and protein phosphorylation by a newly synthesized selective inhibitor of cyclic AMP-dependent protein kinase, $\mathrm{N}$-[2- $(p-$ bromocinnamylamino)ethyl]-5-isoquinolinesulfonamide $(\mathrm{H}-89)$, of 
PC12D pheochromocytoma cells Journal of Biological Chemistry 265 5267-5272

Chirgwin JM, Przybyla AE, MacDonald RJ and Rutter WJ (1979) Isolation of biologically active ribonucleic acid from sources enriched in ribonuclease Biochemistry 18 5294-5299

Choi EJ, Xia Z and Storm DR (1992) Stimulation of the type III olfactory adenylyl cyclase by calcium and calmodulin Biochemistry $\mathbf{3 1}$ 6492-6498

Davis JS (1992) Modulation of luteinizing hormone-stimulated inositol phosphate accumulation by phorbol esters in bovine luteal cells Endocrinology 131 749-757

Davis JS, Weakland LL, Coffey RG and West LA (1989a) Acute effects of phorbol esters on receptor-mediated IP3, cAMP, and progesterone levels in rat granulosa cells American Journal of Physiology 256 E368-E374

Davis JS, Tedesco TA, West LA, Maroulis GB and Weakland LL (1989b) Effects of human chorionic gonadotropin, prostaglandin F2 $\alpha$ and protein kinase $C$ activators on the cyclic AMP and inositol phosphate second messenger systems in cultured human granulosa-luteal cells Molecular and Cellular Endocrinology 65 187-193

Dessauer CW and Gilman AG (1996) Purification and characterization of a soluble form of mammalian adenylyl cyclase Journal of Biological Chemistry 271 16967-16974

Emala CW, Kumasaka D, Hirshman CA and Lindeman KS (1998) Adenylyl cyclase messenger ribonucleic acid in myometrium: splice variant of type IV Biology of Reproduction 59 169-175

Europe-Finner GN, Cartwright E, Bellinger J, Mardon HJ, Barlow DH and López Bernal A (1997) Identification of Gos messenger ribonucleic acid splice variants in human granulosa cells Journal of Molecular Endocrinology 18 27-35

Fagan KA, Mons N and Cooper DM (1998) Dependence of the $\mathrm{Ca}^{2+}$-inhibitable adenylyl cyclase of C6-2B glioma cells on capacitative $\mathrm{Ca}^{2+}$ entry Journal of Biological Chemistry 273 9297-9305

Ford SL, Abayasekara DR, Persaud SJ and Jones PM (1996) Role of phosphoprotein phosphatases in the corpus luteum: identification and characterisation of serine/threonine phosphoprotein phosphatases in isolated rat luteal cells Journal of Endocrinology 150 205-211

Hanoune J, Pouille Y, Tzavara E, Shen T, Lipskaya L, Miyamoto N, Suzuki $\mathbf{Y}$ and Defer $\mathbf{N}$ (1997) Adenylyl cyclases: structure, regulation and function in an enzyme superfamily Molecular and Cellular Endocrinology 128 179-194

Hurley JH (1999) Structure, mechanism, and regulation of mammalian adenylyl cyclase Journal of Biological Chemistry 274 7599-7602

Iwami G, Kawabe J, Ebina T, Cannon PJ, Homcy CJ and Ishikawa Y (1995) Regulation of adenylyl cyclase by protein kinase A Journal of Biological Chemistry 270 12481-12484

Jacobowitz O and Iyengar R (1994) Phorbol ester-induced stimulation and phosphorylation of adenylyl cyclase 2 Proceedings National Academy of Sciences USA 91 10 630-10634

Jacobowitz O, Chen J, Premont RT and Iyengar R (1993) Stimulation of specific types of Gs-stimulated adenylyl cyclases by phorbol ester treatment Journal of Biological Chemistry 268 3829-3832

Jalkanen J, Ritvos O, Huhtaniemi I, Stenman UH, Laatikainen T and Ranta T (1987) Phorbol ester stimulates human granulosa-luteal cell cyclic adenosine 3',5'-monophosphate and progesterone production Molecular and Cellular Endocrinology 51 273-276

Kawabe J, Iwami G, Ebina T, Ohno S, Katada T, Ueda Y, Homcy CJ and Ishikawa Y (1994) Differential activation of adenylyl cyclase by protein kinase C isoenzymes (published erratum appears in Journal of Biological Chemistry 26922 912) Journal of Biological Chemistry 269 16 554-16558

Krupinski J, Coussen F, Bakalyar HA, Tang WJ, Feinstein PG, Orth K, Slaughter C, Reed RR and Gilman AG (1989) Adenylyl cyclase amino acid sequence: possible channel- or transporter-like structure Science 244 1558-1564

Leech CA, Castonguay MA and Habener JF (1999) Expression of adenylyl cyclase subtypes in pancreatic beta-cells Biochemical and Biophysical Research Communications 254 703-706

López Bernal A, Buckley S, Rees CM and Marshall JM (1991) Meclofenamate inhibits prostaglandin E binding and adenylyl cyclase activation in human myometrium Journal of Endocrinology 129 439-445

López Bernal A, Bellinger J, Marshall JM, Phaneuf S, Europe-Finner GN, Asboth G and Barlow DH (1995) G protein expression and second messenger formation in human granulosa cells Journal of Reproduction and Fertility 104 77-83

Mamluk R, Defer N, Hanoune J and Meidan R (1999) Molecular identification of adenylyl cyclase 3 in bovine corpus luteum and its regulation by prostaglandin F2 $\alpha$-induced signalling pathways Endocrinology 140 4601-4608

Mhaouty-Kodja S, Bouet-Alard R, Limon-Boulez I, Maltier JP and LeGrand C (1997) Molecular diversity of adenylyl cyclases in human and rat myometrium. Correlation with global adenylyl cyclase activity during mid- and term pregnancy Journal of Biological Chemistry 272 31 100-31106

Michael AE and Webley GE (1991) Prior exposure to gonadotrophins prevents the subsequent antigonadotrophic actions of cloprostenol by a cyclic AMP-dependent mechanism in cultured human granulosa cells Journal of Endocrinology 131 319-325

Michael AE and Webley GE (1993) Roles of cyclic AMP and inositol phosphates in the luteolytic action of cloprostenol, a prostaglandin $F_{2 \alpha}$ analogue, in marmoset monkeys (Callithrix jacchus). Journal of Reproduction and Fertility 97 425-431

Morimoto BH and Koshland DE, Jr (1994) Conditional activation of cAMP signal transduction by protein kinase $C$. The effect of phorbol esters on adenylyl cyclase in permeabilized and intact cells Journal of Biological Chemistry 269 4065-4069

Premont RT, Chen J, Ma HW, Ponnapalli M and Iyengar R (1992) Two members of a widely expressed subfamily of hormone-stimulated adenylyl cyclases Proceedings National Academy of Sciences USA 89 9809-9813

Premont RT, Matsuoka I, Mattei MG, Pouille Y, Defer N and Hanoune J (1996) Identification and characterization of a widely expressed form of adenylyl cyclase Journal of Biological Chemistry 271 13 900-13907

Price SA, Pochun I, Phaneuf S and López Bernal A (2000) Adenylyl cyclase isoforms in pregnant and non-pregnant human myometrium Journal of Endocrinology 164 21-30

Raimundo S, Giray J, Volff JN, Schwab M, Altenbuchner J, Ratge D and Wisser $\mathbf{H}$ (1999) Cloning and sequence of partial cDNAs encoding the human type $\mathrm{V}$ and $\mathrm{VI}$ adenylyl cyclases and subsequent RNA-quantification in various tissues Clinica Chimica Acta 285 155-161

Ristimäki A, Jaatinen R and Ritvos O (1997) Regulation of prostaglandin F2 alpha receptor expression in cultured human granulosa-luteal cells Endocrinology 138 191-195

Shinohara O, Knecht M and Catt KJ (1985) Inhibition of gonadotropin-induced granulosa cell differentiation by activation of protein kinase $\mathrm{C}$ Proceedings of National Academy of Sciences USA 82 8518-8522

Stevens PA and Pyne NJ (1995) The inhibition of adenylyl cyclase activity in isolated lung membranes by muscarinic and alpha-adrenoceptor agonists: role of G-protein alpha and beta gamma sub-units Cellular Signalling 7 157-163

Sunahara RK, Dessauer CW and Gilman AG (1996) Complexity and diversity of mammalian adenylyl cyclases Annual Review of Pharmacology and Toxicology 36 461-480

Taussig R and Gilman AG (1995) Mammalian membrane-bound adenylyl cyclases Journal of Biological Chemistry 270 1-4

Tesmer J and Sprang SR (1998) The structure, catalytic mechanism and regulation of adenylyl cyclase Current Opinion in Structural Biology $\mathbf{8}$ 713-719

Watson PA, Krupinski J, Kempinski AM and Frankenfield CD (1994) Molecular cloning and characterization of the type VII isoform of mammalian adenylyl cyclase expressed widely in mouse tissues and in S49 mouse lymphoma cells Journal of Biological Chemistry 269 28893-28898

Wei J, Wayman G and Storm DR (1996) Phosphorylation and inhibition of type III adenylyl cyclase by calmodulin-dependent protein kinase II in vivo. Journal of Biological Chemistry $27124231-24235$

Wheeler MB and Veldhuis JD (1989) Facilitative actions of the protein kinase-C effector system on hormonally stimulated adenosine $3^{\prime}, 5^{\prime}$ - 
monophosphate production by swine luteal cells Endocrinology 125 2414-2420

Yan SZ, Hahn D, Huang ZH and Tang WJ (1996) Two cytoplasmic domains of mammalian adenylyl cyclase form a Gs $\alpha$ - and forskolin-activated enzyme in vitro. Journal of Biological Chemistry 271 10941-10945

Yan SZ, Huang ZH, Shaw RS and Tang WJ (1997) The conserved asparagine and arginine are essential for catalysis of mammalian adenylyl cyclase Journal of Biological Chemistry 27212 342-12 349
Yan SZ, Huang ZH, Andrews RK and Tang WJ (1998) Conversion of forskolin-insensitive to forskolin-sensitive (mouse-type IX) adenylyl cyclase Molecular Pharmacology 53 182-187

Received 10 April 2000.

Accepted 7 September 2000. 